\section{alsunilyat}

\title{
The Use of Quizizz Online Software in the Evaluation of Arabic Learning
}

\author{
Nisa Tazkiya Al Munawaroh \\ Universitas Pendidikan Indonesia Bandung, Indonesia \\ E-mail: nisatazkiyaalmunawaroh@ student.upi.edu
}

\begin{abstract}
:
Evaluation is an important stage in learning because it provides information about the implementation of the teaching and learning process and Arabic lessons. However, the evaluation media used are sometimes not as expected and do not provide convenience for the teacher. It also makes students respond negatively to learning. This study aims to explore and describe Quizizz online software as a medium that facilitates the learning process. Participants in this study were an Arabic teacher and students of Senior High School 11 Bandung. The approach used in this research is descriptive qualitative. This study indicates that the use of Quizizz online software in evaluating Arabic learning contains principles that make it easier for teachers to process and get positive responses from students.
\end{abstract}

Keywords:

Arabic language; Learning evaluation; Quizizz online software

\section{INTRODUCTION}

Many experts have expressed their thoughts and ideas about evaluation. Evaluation is a systematic and continuous process to determine the quality (value and meaning) of something, based on specific considerations and criteria to make a decision (Arifin, 2013). Evaluation in learning is carried out the benefit of making a decision, for example, regarding the selection of an approach, method, or technique in a study.

In a state of decision-making in the learning process, evaluation is crucial because it provides information about the implementation of the teaching and learning process to function as a helper and controller for implementing the teaching and learning process (Riadi, 2017). The assessments have a role in supervising learning progress, results, and analyzing needs to improve students' continually studying results (Laili, 2020).

Furthermore, a learning result is a regular cycle of educational activity. Evaluation becomes common and can flow with unrestricted flow. Taken for granted, it often does so improperly, without careful planning and strategy, directionless, and so forth (Kholisoh, 2018). Thus, evaluation in the learning process is essential, as well as in learning Arabic.

Arabic is the language chosen as prophets' language and Alquran as the source of Islamic law. Besides, Arabic has become an international language (Nurbayan, 2015). Also, Arabic is one of the subjects studied at formal educational institutions in Indonesia, from elementary to high school and even universities. Senior High School 11 Bandung is one of the 
public high schools where the curriculum includes Arabic lessons as part of specialization lessons. However, there is a unique fact that some students who attend Senior High School 11 Bandung are not moslem but they are non-moslem. Therefore, it is not surprising that some students are still unfamiliar with hijä'iyah and Arabic script writing. It cannot be denied that Arabic is one of the language lessons that are considered complicated and difficult to learn. In contrast to English, the discourse on education and Arabic development in Indonesia appears to be underdeveloped, even though the majority of Indonesia's population is muslim (Nurbayan, 2010).

Based on the questionnaire, many students often complain about Arabic lessons. They also think that Arabic lessons are difficult and tedious. These facts in the field cause students to evaluate learning at random, and this is a big concern for teachers who teach Arabic lessons.

In the implementation, evaluation has several basic principles. It must be considered as follows: (1) continuity principle, (2) comprehensive principle, (3) objectivity principle, (4) validity principle (validity) and reliability, (5) the principle of using criteria, (6) the principle of usability, (7) the principle of cooperation, (8) the principle of practicality (Sudaryono, 2012). Apart from these principles, one of the principles of evaluation is practical. Practical means easy to use, both for people who evaluate in the preparation of evaluation tools and others who will use them (Arifin, 2012).

Among the principles of evaluation, there are the principles of sustainability and practice. Based on the observations and interviews at Senior High School 11 Bandung, these principles are not fulfilled initially. The evaluation process does not contain practical principles so that the evaluation process is not carried out routinely and continuously. At first, evaluations or exams are carried out with media such as paper. Every time they hold a test, the Arabic teacher must duplicate the question files as many as the number of students so that Arabic writing is clear and can be read by students, especially for those who are still weak in recognizing hijä'iyah. Then, the writing must be printed in large sizes.

Usually, the size used in writing hijā'iyah is more than 18. Also, at Senior High School 11 Bandung, especially in $10^{\text {th }}$ Language class, some students are not moslem, which means they are also still unfamiliar with hijä'iyah, so the Arabic subject teacher decides that every question written in Arabic will also be written in Latin script to make it easier for them. However, this means that in each test, the questions' paper must be duplicated according to the number of students. This makes evaluation impractical and uneconomical. 
Evaluation with conventional media seems to be a problem that must be resolved to overcome. This is not only a problem for Arabic teachers at Senior High School 11 Bandung but for every teacher who teaches Arabic in various other educational institutions with the same problem. There are challenges and facts for teachers or lecturers who teach Arabic, that conventional Arabic learning requires a change into a new method and a real action to answer all the problems that arise (Ali, 2018). An Arabic teacher must improve his quality. It's because the teacher's quality is one of the keys to the student's success in academics, and reality shows that the teachers mainly concern about how to ensure and improve the students achievement in the learning process (Sanusi, et al., 2020).

Today, education has shifted according to the age's development and experiencing rapid changes with digital technology, where these technologies are used in the interests of educational improvements and quality (Khaerunnisa, 2019). The rapid progress and development of information technology have begun to enter the world of education. Information technology is starting to be widely used to support the learning process (Ilmiyah, \& Sumbawati, 2019).

Furthermore, Indonesia recognizes the importance of preparing a creative, capable, and proactive generation of young people (Mubarok in Umamah \& Muassomah 2020). With the development of technology in high schools, especially at Senior High School 11 Bandung, students are already proficient and like technology. This is evidenced by the results of observations and interviews with $10^{\text {th }}$-grade students. The students like learning with technology. This is evidenced by the large number of students who are "gamers", and many of them taking online learning applications, such as Ruang Guru, Quipeer, Kahoots, and others. Therefore, it is better if the learning process and evaluation process are adjusted to the culture needed and liked by students.

Quizizz is online software that can be used as an evaluation medium. It also looks attractive with a ranking system supported by modern school facilities, which can attract students' attention in the process of evalating Arabic learning. Also, using this online software can make it easier for teachers to process student grades.

Thus, the focus of this research is "Quizizz Online Software As A Media For Evaluation Arabic Learning" where this research is carried out to analyze and describe the evaluation of Arabic learning using evaluation media in the form of online Quizizz software, from the utilization process, which includes initial concepts, strategies, objectives, principles, functions, 
steps/procedures, constraints and obstacles, and the advantages and weakness of Quizizz online software, to the response of students and their impact on learning Arabic.

The Arabic teacher at Senior High School 11 Bandung makes the use of the online Quizizz software to implement the evaluation. The initiative to use the online Quizizz software is based on the followings: (1) Evaluation can be carried out continuously and in the process, it is more practical, economical, and does not waste time, (2) $10^{\text {th }}$ Language Class students think that Arabic is religious language and not comparable to other language lessons, (3) making Senior High School 11 Bandung students closer to technology.

Based on these reasons, the Arabic teacher at Senior Highschool 11 Bandung takes the initiative to use online Quizizz software in learning evaluation. Besides following its mission of 'aliman' which means mastering science, technology, and skills, this method is also a form of support in realizing the vision of Senior High School 11 Bandung, which makes students proficient in technology. The Arabic teacher hopes that online Quizizz software in learning evaluation can change students' thought about Arabic and improve the previous evaluation system that has been done before.

Online Quizizz software research has been widely studied, including Ulfah Fauziyyah in her research. She was conducted at Senior High School 1 Majalaya. The result shows that there is an effect of Quizizz media's use on the learning motivation of Senior High School 1 Majalaya students. The learning motivation of students who take learning using Quizizz media is better than students who take learning using conventional media (Fauziyyah, 2019).

Hasanah Devi Hana, in her research, indicates that media Quizizz can increase student enthusiasm for learning (Hana, 2019). Furthermore, Agung Setiawan, Sri Wigati, and Dwi Sulistyaningsih, in their research, indicate a significant increase in the observation results of students' process skills in the learning process through the Quizizz game (Setiawan, et al., 2019).

From some previous studies, it can be concluded that no one has explored further regarding the use of online Quizizz software as a medium in learning evaluation. Previous research only focused on students as the object of their research and its effect on their learning behavior after using Quizizz. Besides, the research method used in the previous research was a quantitative approach, while the approach used in this study was qualitative so that the explanation could be described in more detail. 


\section{METHOD}

The approach used is qualitative descriptive. Participants come from related parties who have a relationship in this study by providing some informations. The participants are Arabic teachers, Mrs. Ajeng, and students in the 10 th Language Class of Senior High School 11 Bandung.

Data collection techniques used in this study are observation, interviews, and documentation. This technique is known as the triangulation technique as a data validity technique. (1) observations were made to observe carefully and precisely how the procedures/steps for using Quizizz online software in the evaluation of Arabic learning. (2) interviews were conducted to obtain detailed information from informants regarding the use of online Quizizz software in evaluating Arabic learning, the advantages and disadvantages of online Quizizz software in evaluating Arabic learning, and students' responses to Quizizz online software in evaluating Arabic learning. (3) a documentation study in the form of a questionnaire compiled via google form which was distributed to all students of the $10^{\text {th }}$ Language Class of Senior High School 11 Bandung. The distribution of this questionnaire was conducted to determine students' response in 10th Language Class regarding online Quizizz software in evaluating Arabic learning.

The data analysis technique used is the data analysis technique of Miles dan Huberman, (1992) which consists of data reduction, data presentation, and conclusions and verification. (1) data reduction is carried out in selecting the main things, focusing on the essential things, looking for themes and patterns. (2) the presentation of data is carried out in brief descriptions, charts, relationships between categories, flowcharts, and the like. (3) conclusions are carried out as a verification step during the research. The initial conclusions put forward are still provisional, which will change if supporting evidence is not found.

\section{RESULTS AND DISCUSSION}

The researcher will describe the results of a study based on the following topics: (1) utilization of Quizizz online software in the Arabic learning evaluation includes initial concepts, strategies, goals, principles, measures, obstacles, and solutions, and its effect on learners already applied to Senior High School 11 Bandung, (2) a different and lacking Quizizz online software in the Arabic learning evaluation, (3) response on the Quizizz online software in the Arabic learning evaluation. 


\section{The Use of Quizizz Online Software for Evaluation of Arabic Learning}

Early concepts of Quizizz online software are derived from one of the school policies. The policy also stems from its vision and mission of Senior High School 11 Bandung. Since 2015, a learning evaluation at Senior High School 11 Bandung implementation (PAS/PAT) has begun using edubox. It is already being done online or CBT (Computer Based Learning), which means that if a high school evaluation is completed online, it's acceptable for each lesson to implement an online evaluation system and back to the teacher on each lesson.

The policy aims to shorten the answer inspection time and encourage teachers to recapitulate learners' data values. Also, there are profitable features for teachers, including the graphic features of the student's increase and drop in value. Finally, Mrs. Ajeng as an Arabic teacher chooses Quizizz online software as a media evaluation for Arabic learning.

\section{The Strategy of Quizizz Online Software Utilization}

The implementation of an evaluation with Quizizz means that it utilizes online or generally called e-learning. Since this evaluation requires networking, surely teachers need school support of usable support facilities. To promote and improve the quality of learning, having established a fitting CBT, Senior High School 11 Bandung provides networking for teachers who teach using the internet. Each teacher could coordinate with technology and information staff to connect the networking in the classroom.

Quizizz online software utilization into the evaluation of Arabic learning became a significant concern to the Arabic teacher so that during the evaluation process, everything went well. The strategy is good cooperation between school, technology and information staff, teacher, and also students. Mrs. Ajeng pointed out that the strategy used was in cooperation with the school authorities, with its consent, and with the power. In the learning evaluation using Quizizz, not only teachers are involved, but participants will be involved and participate in it. The students are indeed the one who does the evaluation, while technology and information staff is the power of monitoring and controlling if there are students who do not fit the requirements.

The participation and the role of teacher and students in the Quizizz assessments of learning with Quizizz indicate active participation, meaning that teachers are well prepared and are indeed already very proficient at the learning evaluation with Quizizz and students are open and receive the system. 


\section{The Purpose of Online Quizizz Software Utilization for Evaluation of Arabic Learning}

Evaluation by Quizizz aims to increase students' interest and stimulate them to participate in learning, especially in this class. Some students are not muslim. Thus, their abbilities are still low in recognizing hijā'iyah letters. Besides, there are some goals of this research such the students use their smartphones to learn, not just to play games, take advantage of the facilities and facilities provided by the school, facilitate the work of teachers in checking student results, minimize and streamline errors during the examination, more accurate and time used more effectively, and helps schools in realizing their mission. We can conclude that using this Quizizz is to determine the progress of the learning process and the achievement of learning objectives by creating students who are sensitive to technology and have high enthusiasm for learning Arabic.

Meanwhile, Mrs. Ajeng suggested the purpose of evaluation by Quizizz for Arabic learning is not only because of the learning to be achieved but also because the principles of evaluation are fulfilled. Based on the past problems, the evaluation's implementation was challenging to do continuously or routinely, but with Quizizz, the implementation of Arabic language evaluation at Senior High School 11 Bandung was routine. Accordance with one of the principles of learning evaluation, namely the continuity principle. The evaluation of best learning outcomes is an evaluation that is carried out continuously. The teacher provides evaluation to students so that the conclusions drawn will be more accurate (Sudaryono, 2012, p. 55).

Besides, another problem in this study is that evaluation is impractical and economical. Quizizz's evaluation does not need to print paper, check answers one by one, steal more time when teaching to check student tests. It proves that using Quizizz means that one of the principles of learning evaluation has been fulfilled, namely the principle of practicality. It is under the theory, which states that there must be practical principles in evaluation. Practical means were easy to use, both for people who evaluate the preparation of evaluation tools and other people who will use them (Arifin, 2012).

\section{The Principles of Online Quizizz Software Utilization}

Learning evaluation has several basic principles. As previously explained, some of the reasons that become the background in this study are the failure to fulfill continuity and practical principle. However, based on an interview after conducting a learning evaluation using Quizizz four times in the last semester, Mrs. Ajeng explained that by using Quizizz, 
practical and sustainable principles have been fulfilled. In accordance with the problems stated previously, the expectations and objectives of evaluation by utilizing this quiz are the achievement of all evaluation principles.

Based on the interview results and corroborated by existing documentation studies, by using a Quizizz, the teacher does not need to take out a paper to duplicate questions and check them one by one. Besides, because of its practical nature, the evaluation process can be carried out continuously.

\section{The Function of Online Quizizz Software Utilization for Evaluation of Arabic Learning}

Evaluation of Arabic learning by Quizizz online software was first used last year in 2019. During 2019/2020, Arabic learning evaluation using Quizizz online software has been carried out more than three times, until last yesterday it was very often done because learning must be done online. As stated by Mrs. Ajeng that learning evaluation using Quizizz has been done very often, maybe more than three times. Because she not only used it for exams but also used it for quizzes. It is also under the interviews with students who stated that the learning evaluation with Quizizz had been carried out more than three times.

Evaluation certainly has a function in learning. In this study, Mrs. Ajeng performed a formative evaluation function. Because this quiz was conducted after the material about the color chapter was completed to measure the extent to which students understood the color material in Arabic. Under the theory, it categorizes the evaluation function into two types, namely the formative function and the summative function (Suryani, 2017). Because Mrs. Ajeng did this quiz after the color chapter was finished, this study's evaluation function was categorized into a formative function. Formative evaluation is an evaluation carried out by the teacher during its development or implementation of a semester teaching program. The purpose of the evaluation is to know the possibility of irregularities and inconsistencies in the implementation of the previously prepared plan as soon as possible. Because it is carried out after finishing teaching a teaching unit (such as a topic or subject), it is found that there is a discrepancy, it can be immediately corrected and corrected.

\section{The Steps of Quizizz Online Software Utilization}

The use of Quizizz includes various stages, from planning, creating questions, entering questions, the evaluation process until the result of the evaluation appear and it is decided what should be considered and improved. Based on the results of the interview with Mrs. Ajeng, the 
researcher arranged the steps taken in the use of the evaluation of Arabic learning with Quizizz online software as follows:

First is the planning and design stage. This stage includes planning and making questions and entering questions into Quizizz. The initial steps that must be taken are as follows: plan and make the questions and search some picture in keeping with the questions. Then, login into Quizizz. The teacher can put the questions in Quizizz with a laptop or smartphone. After entering the home, choose the activity icon and make a quiz. Give a name to the quiz that will be made under the question material given to students. After that, select a subject that is relevant and selects the following icon. Choose the type of quiz to be played. There are multiple choice options, check box, fill in the blank, selection, and open-ended. Each question can be selected differently. However, this time Mrs. Ajeng chose the multiple-choice type for all questions.

In Quizizz, several features can be used and utilized, such as adding media in the form of images and audio or video. In this evaluation, Mrs. Ajeng only inserted pictures. Besides, there is also a feature to set the time, which can be adjusted by considering students' abilities and the quality of the questions. Each question can choose a different time. After that, do not forget to set the features provided by Quizizz as needed and mark the correct answers. Then, choose the save icon. When finished, select the new question icon until all questions have been entered.

After all the questions are entered, a page will appear to fill in the quiz details by filling in the select language column, selecting the class, and who can see this quiz, whether it can be seen for the public or only for private. When done, select the save icon. The quiz has been saved. Quizizz will show all the questions that we have entered along with their answers. The next step is to double-check all the questions. Mrs. Ajeng said that in this case, a teacher must be meticulous, especially in Arabic lessons, which usually mix the letters of the alphabet and the hijā'iyah letters. There should be no errors in writing both in Indonesian and Arabic.

After ensuring that all the questions are correct and there are no mistakes or typos or errors in writing, we can try it out by playing the quiz with its practice feature. Then, the next step is to choose the features that are on Quizizz. One of the advantages of Quizizz is that it has many features, one of which is how to play this quiz. The options available play live or do homework. Mrs. Ajeng chooses to do homework because even though the students did it during class time, they did it in their own homes. By using the choice of homework, we have to arrange 
when students have to complete the quiz. Available date and time column accurately. After that time is up, the student will not be able to enter the quiz, so it can be said that he/she did not take the quiz. After that, select the continue icon. Then the page will come out as shown below. We can share the link or ask students to open the Quizizz and enter the code that has been given.

\section{Figure 1}

\section{The Page to Share Link}

\section{Berbagi link}

or

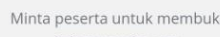

joinmyquiz.com

8250902

The second, the implementation stage. This stage is the quiz implementation process. We can see how the use of quizzes in evaluating Arabic learning. At the previous meeting, of course, Mrs. Ajeng had told all students of the 10 th Language Class that the following learning quiz would be held. All students had prepared their knowledge and understanding of the color chapter. Mrs. Ajeng checks students' attendance online, and they just need to put a checkmark next to their name on the list of names that have been written on the group at that time.

After ensuring that all students were present and ready, Mrs. Ajeng gave prior directions regarding the rules that students had to obey during the quiz or evaluation process. Then, Mrs. Ajeng shared the link and quiz code that had been prepared in advance. After the time limit runs out, Mrs. Ajeng informs the students again. Because they have checked the attendance list at the beginning of the lesson, all students take a quiz on that day. This system runs after doing online learning.

The third is the final stage. This stage is the final stage in the process of using Quizizz online software. The results of the quiz that have been implemented can be downloaded and stored by the teacher immediately. The final grades of students have been processed. The teacher can also see which questions have many wrong answers, which is used as an evaluation material that must be considered.

Based on the research findings previously discussed in the evaluation of Arabic learning, Mrs. Ajeng has demonstrated how the steps in using Quizizz include several stages, starting from planning and designing, the evaluation process, and the final stage sees and 
evaluate the results that have been obtained. This is under the theory, which states that the main steps that must be taken in evaluation activities include: making evaluation plans, collecting data, processing data, interpreting data, and making reports (Arifin, 2014).

\section{The Obstacles and Solutions of Quizizz Online Software Utilization}

Initially, Quizizz online software utilization for evaluation of Arabic learning are not worked out entirety. There were several obstacles, as expressed by Mrs. Ajeng that some of these obstacles, for example the teacher must be able to adjust the questions to essential competencies and lesson plans. During the implementation process, sometimes, some students still have difficulty getting into the software. Moreover, some students suddenly leave and then have to enter again and repeat. Apart from that, the signal also affects.

Some obstacles in Quizizz online software utilization for evaluation of Arabic learning need to be evaluated. Most of the obstacles are the technical problem. Because this Quizizz is included in one example of e-learning, this Quizizz has three components: infrastructure, systems and applications, and the content and teaching materials available in the Quizizz (Rusdy, in Aidah, 2019). At first, Mrs. Ajeng was overwhelmed by the technical problems that arose when students tried to start a quiz.

There are some obstacles without solutions. As Mrs. Ajeng said that the first solution is the teacher must be careful and observant in double-checking the questions, it is feared that students will not understand the questions given. Then, during the implementation process, the teacher must have mastered the Quizizz, so when there are students who have technical difficulties, the teacher already knows what to do.

Besides, technology and information staff also distribute internet access rights. It is according to the theory that states that in the implementation of e-learning based learning, one of the components is infrastructure. This infrastructure can be in the form of an internet network and multimedia equipment (Rusdy, in Aidah, 2019). Thus, the school's solution through the technology and information staff is under the existing theory to create a better learning process.

\section{The Impact of Quizizz Online Software Utilization for Students}

The use of Quizizz for the evaluation of Arabic learning impacts students, both in terms of students' interest and enthusiasm in learning and learning outcomes. Students' learning outcomes after using Quizizz are better compared to learning evaluations with conventional media. The learning process to the evaluation of learning shows that students' enthusiasm and 
responsibility towards their learning have increased, resulting in good learning outcomes; as stated by Mrs. Ajeng that the use of Quizizz seems to have a reasonably significant impact on students. That is one reason why Mrs. Ajeng uses Quizizz.

Besides that, Quizizz has various advantages, that Arabic is not just a religious language but can also be aligned with other language lessons, such as English and Japan. Then, apart from those who are not moslem and inactive students, the use of Quizizz is very suitable for them, because they have to work according to the specified time. Besides, they show improvement in their learning outcomes because they have high motivation to do the best in every quiz.

\section{The Advantages and Weaknesses of Quizizz Online Software Utilization}

Implementation of learning evaluation by Quizizz online software at Senior High School 11 Bandung certainly has some advantages and weaknesses. Based on the results of interviews that have been conducted. According to the Arabic teacher, the advantages of Quizizz online software for evaluation of Arabic learning at Senior High School 11 Bandung can be seen from several sides: (1) for teachers, this software's advantages lie in its Quizizz benefits.

The use of Quizizz makes recapitulating the results of any test or evaluation more practical and easy. Teachers can also evaluate learning continuously according to a predetermined and planned schedule. Apart from that, Quizizz supports Arabic fonts, so when the teacher enters a question with hijiyah characters, the font will not change. (2) for students, they are more challenged to fill in answers correctly and carelessly. Because when the quiz is over, the ranking will be displayed on the quiz. Besides, the use of Quizizzes is very influential, especially for those who are not Muslims and lazy students, as has been explained.

Apart from the things that have been mentioned above, Mrs. Ajeng also explained that Quizizz has many advantages and is suitable for learning evaluation media. These advantages such as: (1) do not change the writing of hijä'iyah letters. When writing Arabic, the writing does not change. The writing remains clear and legible. And then, all chapters in Arabic lessons can use this application for tests or quiz. (2) giving questions is fixated on writing and questions and can also include sound, pictures, and videos so that students understand better about the questions being asked. (3) there are various kinds of features.

Some students of $10^{\text {th }}$ Language Class who acted as the respondents also mentioned some of the advantages of Quizizz. The researcher summarizes the students' answer as follows: (1) practical, faster filling, to the point, and online. (2) make it easier to evaluate learning, especially in the current situation and conditions when learning has to be carried out remotely. 
Quizizz can be done anywhere without a distance limit between the question giver and the one working. (3) when filling out an essay question, just type the answer. (4) the teacher assesses learning quickly. (5) more economical, does not require paper. (6) modern, up to date, and comparable to other language lessons. (7) does not waste much time. (8) it is easier on the eyes. (9) can memorize vocabulary.

The use of Quizizz for the evaluation of Arabic learning certainly has some advantages. Based on the results of interviews by Quizizz, students can learn with or without a teacher, close or long distance, as the opinion states that e-learning is learning uses electronic circuits to deliver learning content, relates or guidance as a form of distance education conducted through computers and the internet (Efendi and Zhuang, in Wibawa, \& Lutfiana, 2019). Because Quizizz can be done remotely, therefore learning evaluation with Quizizz is very suitable nowadays where learning is online.

Another advantage of Quizizz is that it can be done anywhere without a distance limit between the question provider and the one who does it. Under the theory, one of the characteristics of e-learning is that it does not depend on space (place) and time. Learning with this system can be carried out anytime and anywhere (Wahyuningsih, \& Makmur, 2017). The advantage of using Quizizz online software is the evaluation process that is more flexible and efficient and practical, and economical, which means that by using this Quizizz, students can learn independently and a more comprehensive range of learning. Under the theory, there are six advantages of an e-learning system: cost-effectiveness, time flexibility, place flexibility, learning speed flexibility, teaching effectiveness, and on-demand availability (Efendi and Zhuang, in Wibawa \& Lutfiana, 2019).

Apart from having advantages, it cannot be denied that Quizizz online software also has some weaknesses. As Mrs. Ajeng said, these deficiencies are: (1) Sometimes, there are still students who have difficulty entering. (2) some students say they suddenly quit the quiz. (3) Signal. The students of $10^{\text {th }}$ Language Class who acted as the respondent also mentioned some of the Quizizz online software shortcomings. Researchers summarize the students' answers: (1) the lack of interaction between teachers and students. (2) difficult to revisit. (3) time-bound, so they must compete with other students. (4) there are limitations in the use of gadgets for some students. (5) sometimes there are hijä'iyah fonts that cannot appear. One statement of weakness is the lack of teacher-student interaction. It is under the theory, which states that 
there are eight weaknesses or deficiencies in e-learning. One of these shortcomings is the lack of interaction between teachers and students (Munir, 2009).

\section{The Student's Responses of Quizizz Online Software Utilization}

Interviews and questionnaires carried out students' responses to Quizizz online software utilization. Based on the interview results, the responses from students of the $10^{\text {th }}$ Language Class at Senior High School 11 Bandung were very diverse. Mrs. Ajeng said that the students' response was very positive. Sometimes they asked to take quizzes at the Quizizz again. Besides, they become more enthusiastic during the learning process to get the top ranking in the quiz.

Furthermore, the researcher also distributed questionnaires by google form to all students of the $10^{\text {th }}$ Language Class. Based on the questionnaire, the following description is obtained. First, the results of the students' questionnaire answers can be described that out of 34 students. 20 students (59\%) stated that they strongly agreed that the evaluation by using Quizizz made their enthusiasm increase in learning Arabic. 13 students (28\%) stated that they agreed that the evaluation by using Quizizz made their enthusiasm increase in learning Arabic. And 1 student (3\%) stated that he didn't agree with the evaluation by using Quizizz to make them more enthusiastic about learning Arabic.

\section{Figure 2}

The Results Of The Students' Questionnaire Answers About The Evaluation By Using Quizizz Made Their Enthusiasm Increase In Learning Arabic

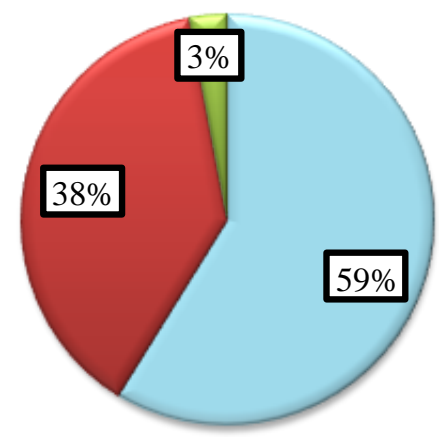

Second, the results of the students' questionnaire answers can be described that out of 34 students, 20 students (59\%) stated that they agreed that evaluation by Quizizz was more interesting than conventional media, and 14 students (41\%) stated that they agreed evaluations with conventional media were more interesting than evaluation by Quizizz. 


\section{Figure 3}

The Results of The Students' Questionnaire Answers About The Evaluation by Quizizz Were More Interesting Than Conventional Media

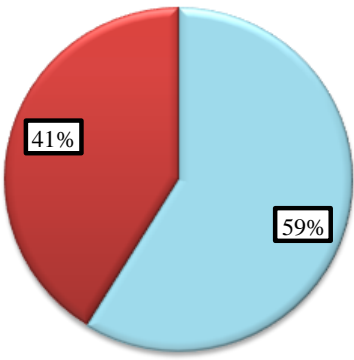

Third, the results of the student's questionnaire answers can be described that out of 34 students, 17 students (50\%) stated that they strongly agreed that evaluation by Quizizz was effective in evaluating Arabic learning, 16 students (57\%) stated that they agreed that evaluation by Quizizz was effective in evaluating Arabic learning , and 1 student (3\%) stated that he did'nt agree with the evaluation by Quizizz was effective in evaluating Arabic learning.

\section{Figure 4}

The Results of The Students' Questionnaire Answers About The Evaluation by Quizizz Was Effective In Evaluating Arabic Learning

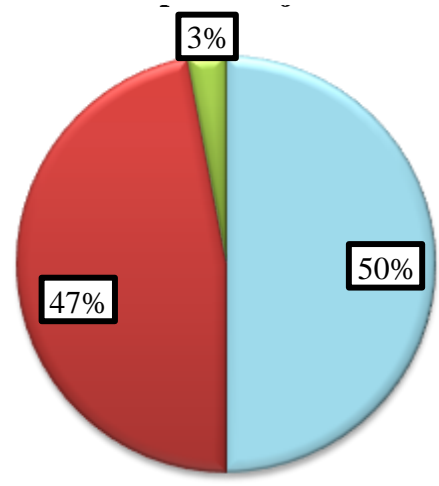

Based on the questionnaire results, it can be concluded that the evaluation of learning Arabic by Quizizz is considered to make them more enthusiastic about learning Arabic, more effective, and more interesting than conventional media by the majority of students. When connected with the answers to each point in the student questionnaire, it can be concluded that students who took the evaluation of learning Arabic with Quizizz made their interest in learning Arabic increase, their assumption of Arabic as a religious language began to change, and they sure that Arabic they are learning is a language lesson that is comparable to other language 
lessons. In addition, by using Quizizz, they feel more challenged and are more active and diligent in learning Arabic.

\section{CONCLUSION}

From the results, the researcher concludes the following conclusions: first, the use of Quizizz online software includes initial concepts, strategies, purposes, principles, functions, steps, constraints, and solutions of Quizizz utilization. Second, the advantages of Quizizz are: it makes the recapitulation of test results or any evaluation more practical and easy, it can carries out the learning evaluation continuously according to a determined and planned schedule, it can supports Arabic fonts, it makes the students interested to fill the Arabic answers correctly and lack of carelessness, it does not change the writing of hijä'iyah letters, it is useful because it includes the sound, images, and videos so that students understand about the questions that being asked, it has various kinds of features, it is also practical, economical, modern, and it can memorizes vocabulary. While the weaknesses of Quizizz are: students have difficulty to enter Arabic words, the students suddenly quit quizzes while doing it, it is unstable connection, it is lack of teacher and student interaction, the students also feel difficult to review, tied up time, compete with other students. Then, some students have limitations in the use of gadgets and sometimes there are hijā'iyah fonts that cannot appear.

Third, evaluation of Arabic learning by utilizing online Quizizz software is considered to make students more enthusiastic about learning Arabic, more effective, and more interesting than conventional media by the majority of students. When connected with the answers to each point in the student questionnaire, it can be concluded that students who takes the evaluation of learning Arabic with Quizizz makes high improvement in learning Arabic. Their assumption of Arabic as a religious language are changed where Arabic is a language lesson that is comparable to other language lessons. In addition, by using Quizizz, they feel more diligent and active in learning Arabic.

\section{REFERENCES}

Aidah, S. (2019). Pemanfaatan e-learning sebagai media pembelajaran di STIA Al Gazali Barru. Mereja Journal, 2(1), 1-12. https://doi.org/https://doi.org/10.33080/mrj.v2i1.20

Ali, J. (2018). Outbond as the alternative method to have fun Arabic learning. Journal of Arabic

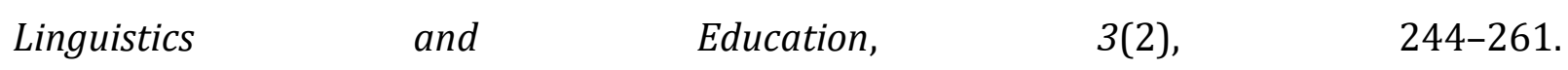
https://doi.org/https://doi.org/10.28918/alsinatuna.v3i2.1276 
Arifin, Z. (2012). Penelitian pendidikan. Bandung: PT Remaja Rosdakarya.

Arifin, Z. (2013). Evaluasi pembelajaran: Prinsip, teknik, prosedur. Bandung: PT Remaja Rosdakarya.

Arifin, Z. (2014). Evaluasi pembelajaran. Bandung: PT Remaja Rosdakarya.

Fauziyyah, U. (2019). Pengaruh media Quizizz terhadap motivasi belajar peserta didik dalam pembelajaran PKN. Skripsi. Universitas Pasundan Bandung.

Hana, H. (2019). Penerapan media pembelajaran Quizizz untuk melatih kemampuan gramatika mahasiswa jurusan sastra Jerman Universitas Negeri Malang. Skripsi. Universitas Negeri Malang.

Ilmiyah, N., \& Sumbawati, M. (2019). Pengaruh media Kahoot dan motivasi belajar terhadap hasil belajar siswa. JIEET: Journal Information Engineering and Educational Technology, 3(1), 46-50. https://doi.org/https://dx.doi.org/10.26740/jieet.v3n1.p[46-50]

Khaerunnisa, F. (2019). Evaluasi penerapan blended learning pada pembelajaran bahasa Arab di SMPIT Ibadurrahman: Studi kasus di Kelas VII Akhwat. Alsuniyat: Jurnal Penelitian Bahasa, Sastra, dan Budaya Arab, 2(2), 95-108. https://doi.org/https://doi.org/10.17509/alsuniyat.v2i2.24808

Kholisoh, L. (2018). Sudahkah evaluasi kemahiran berbicara bahasa Arab pada tingkat dasar dilakukan?. Alsuniyat: Jurnal Penelitian Bahasa, Sastra, dan Budaya Arab, 1(1), 73-87. https://doi.org/https://10.17509/alsuniyat.v1i1.24200

Laili, M. (2020). Ketepatan kontruksi butir pilihan ganda bahasa Arab. Alsuniyat: Jurnal Penelitian Bahasa, Sastra, dan Budaya Arab, 3(2), 111-124. https://doi.org/https://doi.org/10.17509/alsuniyat.v3i2.25272

Miles \& Huberman. (1992). Analisis data kualitatif. Jakarta: Universitas Indonesia Press.

Munir. (2009). Pembelajaran jarak jauh berbasis teknologi informasi dan komunikasi. Bandung: Alfabeta.

Nurbayan, Y. (2010). Pengembangan materi ajar balaghah berbasis pendekatan kontrastif. Jurnal Bahasa dan Seni, 38(1), 107-116. https://doi.org/http://sastra.um.ac.id/wpcontent/uploads/2012/01/11.-Yayan.docx.pdf

Nurbayan, Y. (2015). Penerapan metode imla' dalam pembelajaran menulis bahasa Arab. Almajallat: Antologi Program Studi Pendidikan Bahasa Arab, 3(1), 1-10. https://doi.org/http://antologi.upi.edu/file/artikel_skripsi_rachma_ayu_pratiwi_1006725.doc 
Riadi, A. (2017). Problematika sistem evaluasi pembelajaran. Ittihad Jurnal Kopertais Wilayah XI Kalimantan, 15(27), 1-12. https://doi.org/https://dx.doi.org/10.18592/ittihad.v15i27.1593

Sanusi, A., Sauri, S., \& Nurbayan, Y. (2020). Non-native language teacher: Low teacher's professional competence low quality outcomes?. Arabiyat: Jurnal Pendidikan Bahasa Arab dan Kebahasaaban, $\quad 7(1), \quad 45-60$. https://doi.org/http://dx.doi.org/10.15408/a.v7i1.12722

Setiawan, A., Wigati, S., \& Sulistyaningsih, D. (2019). Implementasi media game edukasi Quizizz untuk meningkatkan hasil belajar matematika materi sistem persamaan linear tiga variabel kelas X IPA 7 SMA Negeri 15 Semarang tahun ajaran 2019/2020. Prosiding Seminar Nasional Edusaintek FMIPA UNIMUS. Semarang: 28 September 2019. 167-173.

Sudaryono. (2012). Dasar-dasar evaluasi pembelajaran. Yogyakarta: Graha Ilmu.

Suryani, Y. (2017). Pemetaan kualitas empirik soal ujian akhir semester pada mata pelajaran bahasa Indonesia di Kabupaten Klaten. Jurnal Penelitian dan Evaluasi Pendidikan, 21(2), 142-152. https://doi.org/http://doi.org/10.21831/pep.v21i2.10725

Umamah, M., \& Muassomah. (2020). Pembelajaran daring melalui teknik kolaboratif pada keterampilan menulis peserta didik di SMA Darul Quran Kota Mojokerto. Alsuniyat: Jurnal Penelitian Bahasa, Sastra, dan Budaya Arab, 3(2), 88-100. https://doi.org/https://doi.org/10.17509/alsuniyat.v3i2.24362

Wahyuningsih, D., \& Makmur, R. (2017). E-learning teori dan aplikasi. Bandung: Informatika.

Wibawa, S., \& Lutfiana, R. (2019). Pengembangan media pembelajaran e-learning pada mata pembelajaran komputer dan jaringan dasar dengan framework laravel di SMK. Jurnal ITEdu, 4(1), 90-95. https://doi.org/https://ejournal.unesa.ac.id/index.php/itedu/article/view/28870 